\title{
Wladimir Köppen, Alfred Wegener, and Milutin Milankovitch: their impact on modern paleoclimate research and the revival of the Milankovitch hypothesis
}

\author{
Jörn Thiede
}

St. Petersburg State University, 7-9, Universitetskaya nab., St. Petersburg, 199034, Russian Federation

For citation: Thiede J. Wladimir Köppen, Alfred Wegener, and Milutin Milankovitch: their impact on modern paleoclimate research and the revival of the Milankovitch hypothesis. Vestnik of Saint Petersburg University. Earth Sciences, 2018, vol. 63, issue 2, pp. 230-250. https://doi.org/10.21638/11701/ spbu07.2018.207

Wladimir Köppen (1846-1940, originally from St. Petersburg), Alfred Wegener (1880-1930, originally from Berlin) and Milutin Milankovitch (1879-1958, originally from Dalj, then Austria-Hungary, today eastern Croatia) made significant contributions to paleoclimatology during the early years of the $20^{\text {th }}$ century. Köppen described the global climate zonation, Wegener defined the continental drift during the Phanerozoic, using Köppen's climate zonations applied to paleogeographic scenarios of the geological past, and Milankovitch introduced regularly changing orbital parameters as controls of past climatic changes providing a precise timescale for Glacials and Interglacials during the Quaternary. By combining their scientific efforts, they succeeded to change our understanding of Earth history fundamentally, each of them with their specific expertise and their wide scientific horizons. Wladimir Köppen's scientific work began with observations from the Crimea and from contributing to produce synoptic weather maps while he was working at the Central Physical Observatory in St. Petersburg. Later he pursued his scientific career at the "Deutsche Seewarte" in Hamburg. While producing numerous scientific papers, he was also engaged in instrumental development (kite technology) and in shaping the organisational framework for meteorology, both nationally and internationally. One of his major scientific achievements was the definition of the global climate zonation which he repeatedly published in global maps and which is still used today.

Keywords: paleoclimatology, Glacials and Interglacials, Milankovitch frequencies, cyclostratigraphy, Wladimir Köppen, Alfred Wegener, Milutin Milankovitch.

\section{Introduction}

This paper has been written for the Vestnik of St. Petersburg State University, Earth Sciences to commemorate the scientific achievements of Wladimir Köppen (1846-1940), who was born in St. Petersburg, had his first scientific position at the Central Physical Observatory of St. Petersburg and developed in young years into one of the globally leading meteorologists. The new Köppen Laboratory of the Institute of Earth Sciences of SPbGU has been named in honor of him, with the aim to remind the active relevant scientific community and the young generations of meteorologists, geographers and paleoclimatologists

(c) Санкт-Петербургский государственный университет, 2018 
in Russia of this important man. St. Petersburg later developed into a "Mekka" of climate and paleoclimate sciences, as can be concluded based on the results of Michael I. Budyko (1920-2001, cf. Budyko, et al., 1987) as well as the researchers who are presently working at various scientific institutions in St. Petersburg. Köppen's $170^{\text {th }}$ birthday was heralded by Khayrullin 2016 in the Proceedings of the Voeikov Main Geophysical Laboratory in St. Petersburg which developed from the Central Physical Observatory, where Köppen had his first position during his early years in St. Petersburg.

The global climate has shown great variability through the Earth's history, but strangely enough the climate extremes never exceeded the narrow window of temperatures (both on the warm as well on the cold end), which allows life to exist, for the past 3-4 billion years (Summerhayes, 2015). The sedimentary records documenting the Earth's history contain evidence for "glacial" events (or glacial climatic phases) of a widely different nature, ranging from "unipolar" glaciations (with huge ice sheets when one of the poles was covered by a large and high continent such as during the Permo-Carboniferous, while the other pole was located in the open ocean and kept ice-free due to the potential advection of temperate waters), the "snowball earth" situation at the end of the Precambrian (when most of our globe apparently was covered by ice) to bipolar glaciations such as during the Cenozoic. At that time, young plate tectonic movements had generated a paleogeographic situation with climatically/oceanographically isolated physiographic provinces on the southern and northern hemispheres. Ideas about the origin of tills and occurrences of erratics (which at that time were considered very strange deposits) as indicators of glaciation, alternating obviously with sediments of a non-glacial nature, started to surface during the early $19^{\text {th }}$ century (Agassiz, 1838; Esmark, 1824).

Sedimentation patterns (stratigraphies) often reveal cyclic repetitions of their properties, following cycles of a wide variety, length and causalities. Schulz et al. (1999) linked 1470-year climate oscillations (Dansgaard-Öschger Interstadials) during the last 100,000 years to fluctuations of continental ice mass. Wang et al. (1999) explained periodicities of 84, 102 and 775 years in Holocene South China Sea records to monsoon variations caused by long-term oscillations in thermohaline circulation and solar activity cycles. Sierro et al. (2000) calibrated Atlantic climatic records to Mediterranean sapropels and astronomical oscillations. But none of these are as important as the variations between Glacials and Interglacials, which seem to follow each other in a cyclical pattern controlled by the Milankovitch frequencies (Past Interglacials Working Group..., 2016) with longer wave lengths than the examples mentioned above. The latter paper puts a focus on the question how Interglacials end, how their paleoclimate gives way to the following Glacials and the authors speculate, how the modern Interglacial's climate may change in the future. This question is of high societal relevance.

It is also of high socioeconomic relevance because our highly developed societies with their complex technologies urgently need scientifically based "early warning systems" of the imminent climatic changes and their environmental consequences which we might experience in the future. It is here, where Köppen, Wegener and Milankovitch made their biggest contribution. 


\section{Wladimir Köppen, his origin and family}

Wladimir Peter (Petrovitch) Köppen (* Sept. 25, 1846 in St. Petersburg, + June 22, 1940 in Graz/Austria, at that time part of the "German Reich") was born into a family with German roots. His grandfather, a physician (Johann Friedrich Köppen, ${ }^{\star} 1752$ in Schwedt/ Oder, +1808 in Kharkov), had been invited by Catherine the Great in 1786 to help with the medical services in the Russian Empire. In 1793 he was appointed the chief physician of the Slobodsko-Ukraine (later Kharkov) government. As a subject of the Russian Empire he was now known by the name Ivan Ivanovich. In 1811, the family was elevated to nobility. The son Pjotr Ivanovitch Köppen (* Febr. 19, 1793 in Kharkov, + May 23, 1864 on the Crimea and father to Wladimir Köppen, who also had three brothers and three sisters) became a noted archeologist, geographer and statistician and was elected member of the (Imperial) St. Petersburg Academy of Sciences.

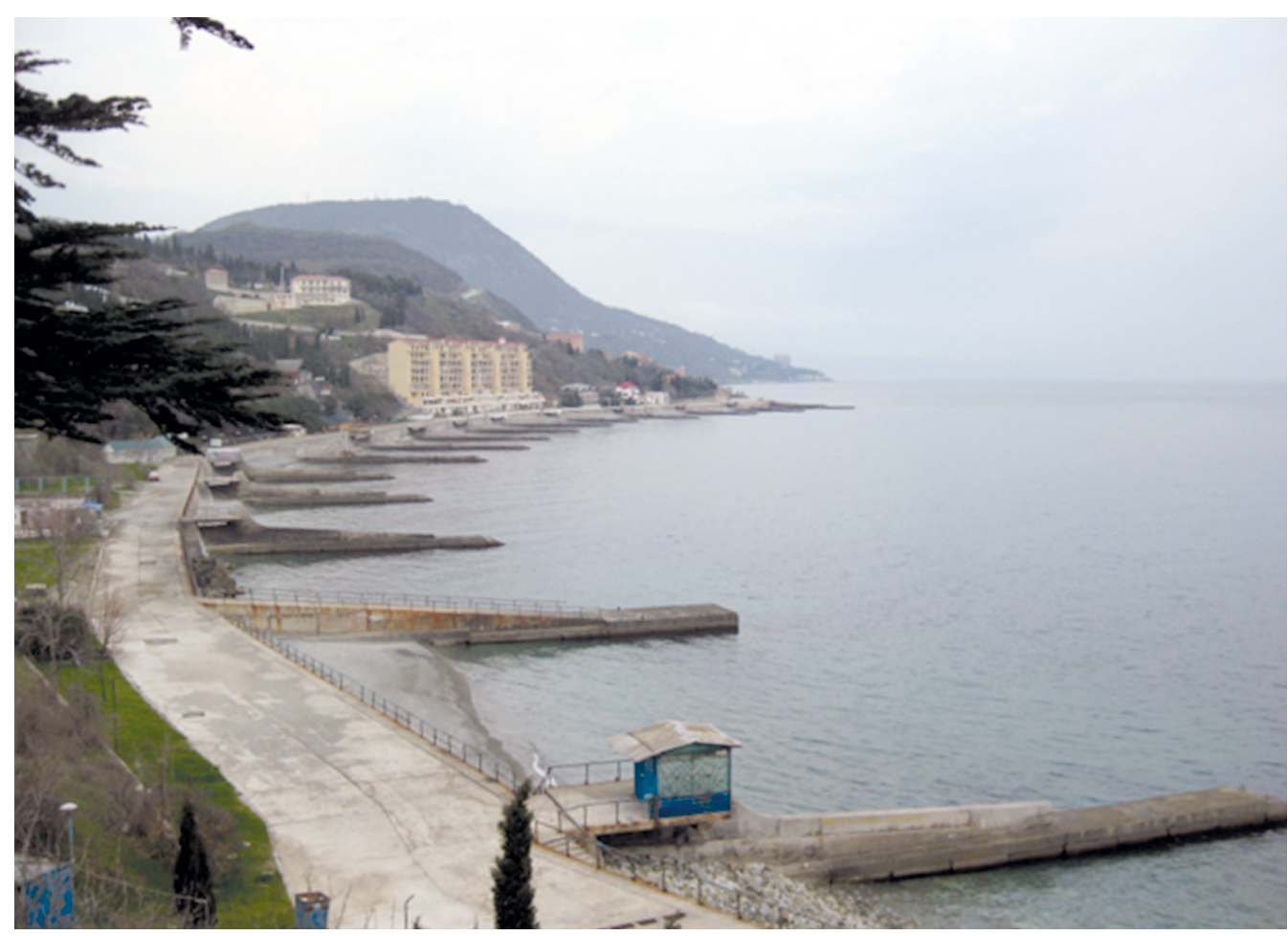

Fig. 1. South coast of the Crimea at Karabakh (today part of the town of Alushta) where the Köppen family owned an estate/vinery

In 1829, he purchased a vinyard on the Crimea's South Coast in the village of Bijuk-Lambat, presently Malyi Mayak (in the area of Alushta), later acquired adjacent parcels of land and finally made this estate his permanent home, named "Karabakh" (Black Vinyard), after the name of the first parcel (Fig. 1). Although the estate was lost after the revolution, family graves (Fig. 2) and memories of the Köppen family (street name in Alushta) are preserved in the area even today. 
Fig. 2. Gravestone of the Köppen-family in Karabakh (Alushta, South coast of the Crimea) where the Köppen-family owned a vinery/estate
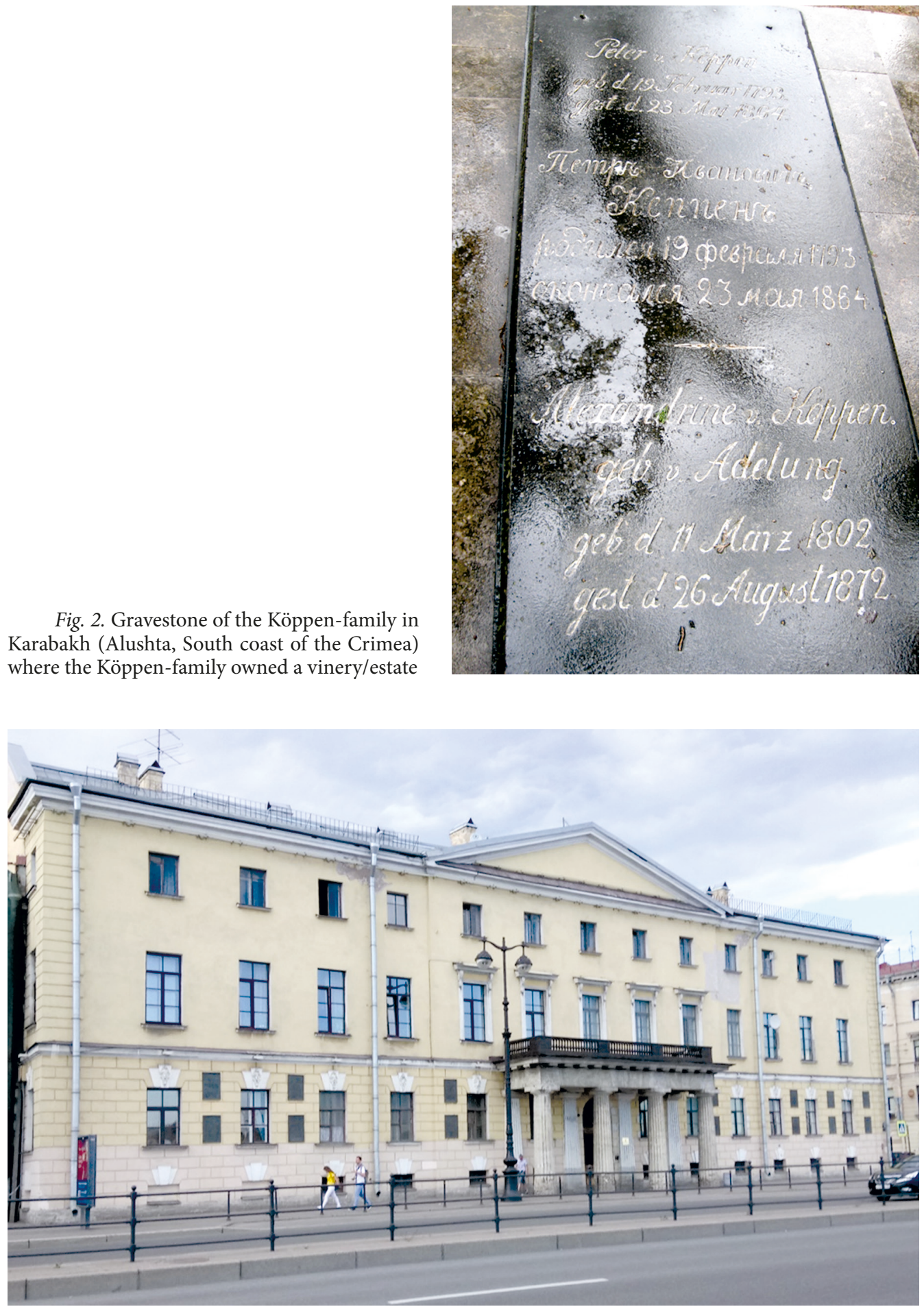

Fig. 3. The "Academicians House" in St. Petersburg in modern time. The black plaques between the windows comemmorate the many famous academicians who have been living here over the years with their families, like the Köppens (Photo: S. Thiede, June 18, 2017) 


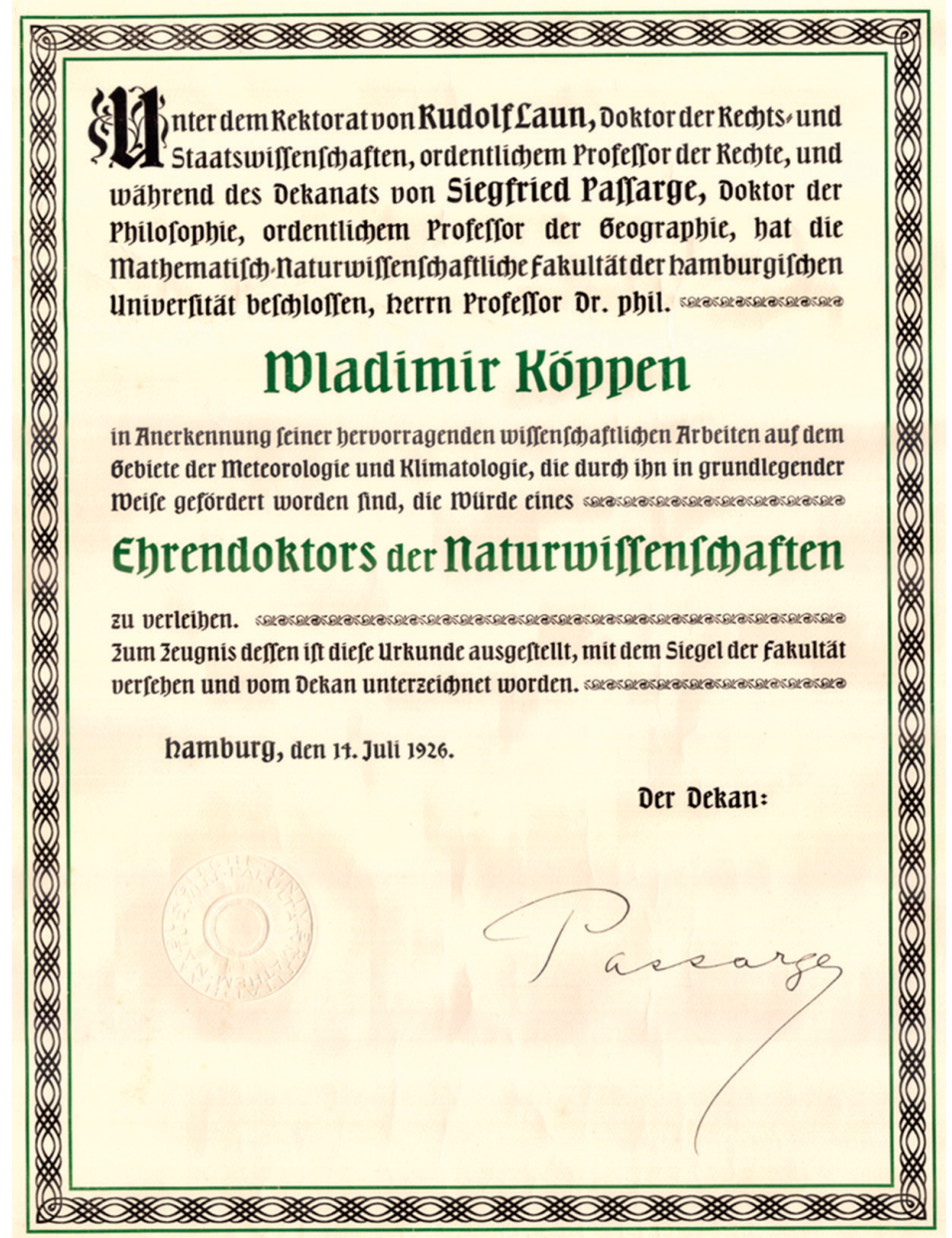

Fig. 4. Certificate of Wladimir Köppens honorary doctoral degree from the University of Hamburg (dated July 14, 1926, courtesy of Dr. Günther Schönharting, Eichhofen/Germany)

Being a member of the Imperial Russian Academy of Sciences, Pjotr von Köppen and his family were also given a flat in the "Academicians House" in St. Petersburg (modern address: nab. Leitenanta Shmidta, nr. 1, Fig. 3) which became famous, also because the Russian Geographical Society was founded in this flat on August 6, 1845. Wladimir Köppen later served 1872-1874 this society as its secretary. He moved from St. Petersburg to Hamburg/Germany in 1875, later from Hamburg to Graz/Austria in 1924 (see details further below). His professional and scientific development can be deduced from his bibliography published in (Wegener and Köppen, 1955).

The young Alfred Wegener got in touch with Wladimir Köppen in the early years of the $20^{\text {th }}$ century because he sought his advice on a number of scientific issues (see below) and began to visit his senior colleague. During this time, Alfred Wegener fell in love with Else, one of Wladimir Köppen's daughters and the scientific liaison soon developed into close family bonds which remained throughout Köppen's life until he died in Graz in 1940. 


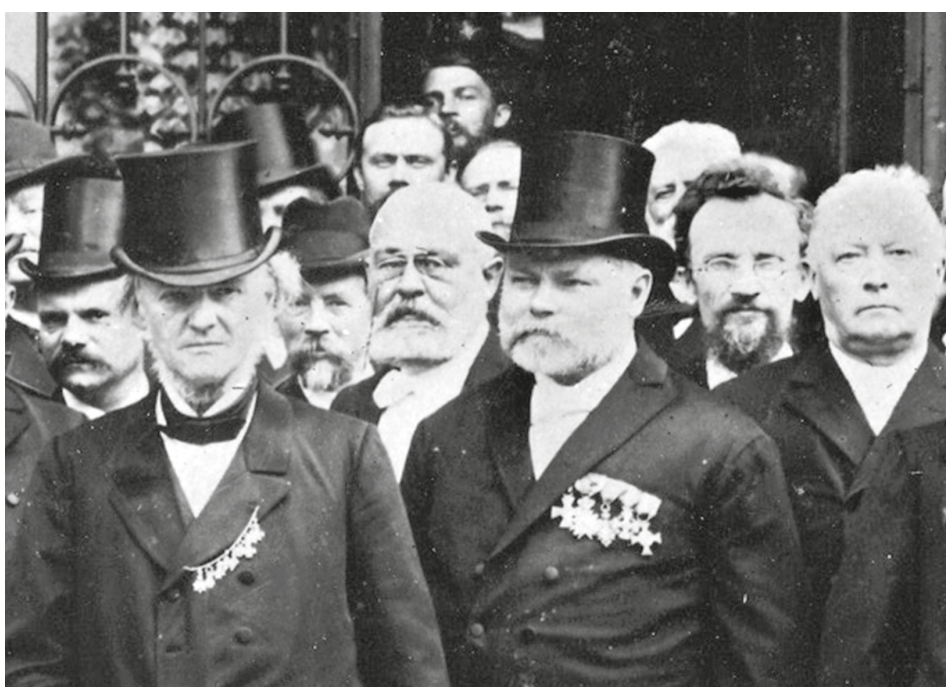

Fig. 5. Photography of celebreties who met at the occasion of the $25^{\text {th }}$ anniversary of the foundation of the "Deutsche Seewarte" on Febr. 1, 1900. G. von Neumayer - $1^{\text {st }}$ left front row, beside him K. Koldewey (leader of the first German North Pole Expedition 1868), Wladimir Köppen (approx. 50 years old) during his active years $2^{\text {nd }}$ from the right (Source: Archive of the "Deutsche Seewarte", today BSH in Hamburg)

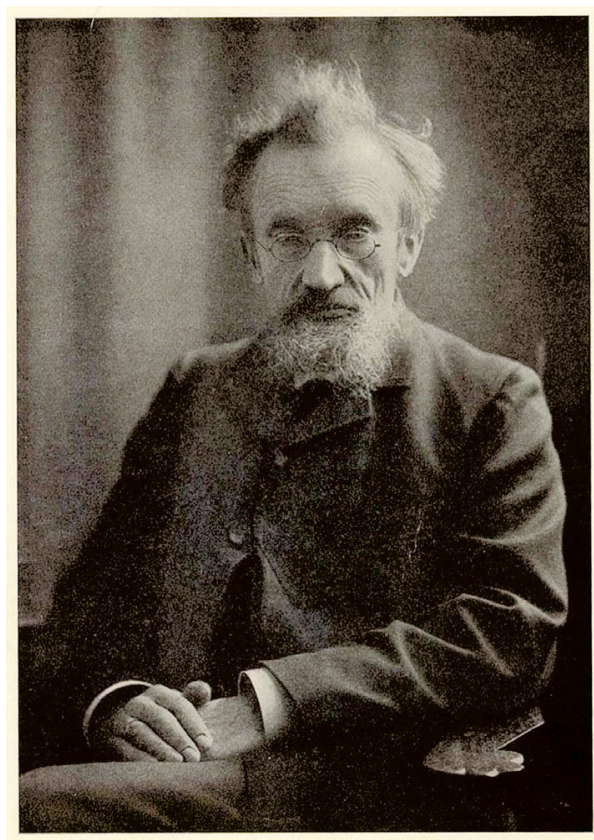

Fig. 6. Wladimir Köppen as an elderly man (courtesy of director of archive of the St. Petersburg State University Library Marina Karpova)

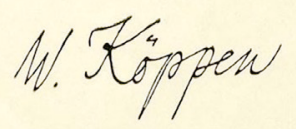




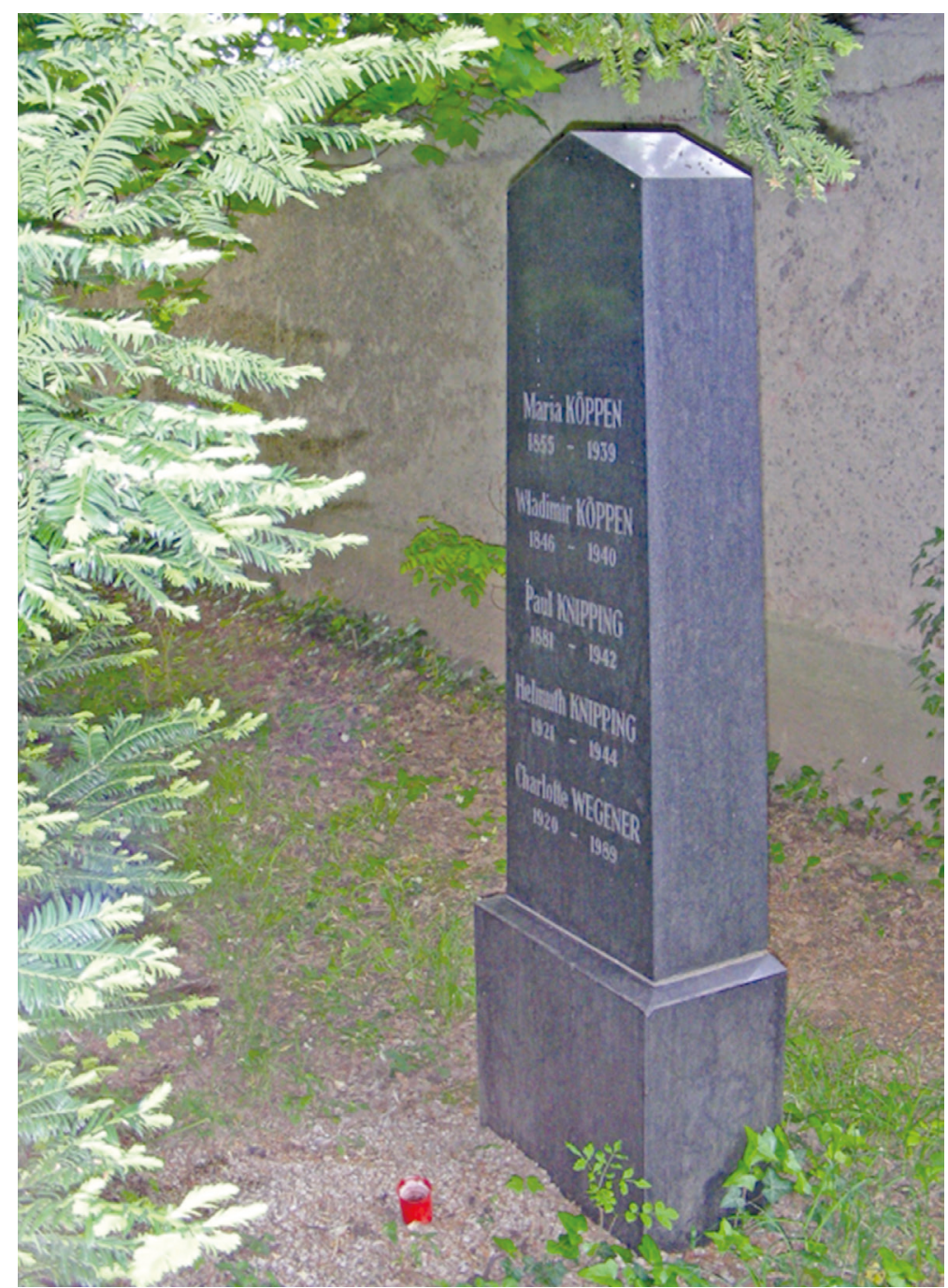

Fig. 7. Gravestone of the Köppen-family in Graz/Austria (Photo: Dr. R. Krause, AWI, Bremerhaven)

Else ( ${ }^{\star}$ Febr. 1, 1892, + Aug. 27, 1992) became the editor of Köppen’s biography ((Wegener and Köppen, 1955), a translation of the German text into Russian is presently being prepared and has been published by the Russian Publishing House Paulsen.ru after in Moscow in May 2018; the original German text will republished together with a translation into English by Borntraeger Science Publishers - Stuttgart during 2018).

Köppen's biography, based on his personal notes, was later published by (Wegener and Köppen, 1955). It revealed also some of his social activities which went far beyond his professional work. Beside his regular duties at his scientific home institution, after some time he also established a relationship to the then very young University of Hamburg. He became a (titular) professor in Hamburg and he received an honorary doctoral degree in 1926 from the University of Hamburg at the occasion of his $80^{\text {th }}$ birthday (Fig. 4). His 
main scientific accomplishments were related to global climate classifications, which were based on a mathematically defined and quantified subdivision of the major climate zones of planet Earth, which - however - are not the subject of this article.

Wladimir Köppen (Figs 5 and 6) stayed for over 40 years at the "Deutsche Seewarte" and was succeeded in 1919 by his son-in-law Alfred Wegener, who in 1924 accepted a professorship in meteorology and geophysics at the University of Graz/Austria. At that time both had established a mature scientific partnership as manifested by their jointly authored book "The Climates of the Geological Past" (Köppen and Wegener, 1924) which also brought them both into close scientific contacts with Milutin Milankovitch. Both families moved from Hamburg to Graz in 1924 and Wegener as well as Köppen continued their active scientific life until they died, Wegener (1930, only 50 years old) towards the end of his famous expeditions to the top of the Greenland ice sheet in 1929/1930, Köppen because of his age in 1940 in Graz. Wegener's death caused much grieve in the families.

Köppen's Russian origin caused some traumatic experiences, although not much is written about this in his biography. During 1870, he finalized his studies at the universities of Heidelberg and Leipzig and became a witness to the many casualties of the German war against France. He then volunteered to serve as a medic for some time. In 1914 WW I broke out, with the Russian and German empires on opposite sides. As an employee ("Beamter, Admiralitätsrat") of the "Deutsche Seewarte" Köppen had to be loyal to his employer. With the communist revolution, the family lost their estate in Crimea and contacts to Russia became very difficult, even though some of the wider family circle remained in Russia. Köppen died in Graz in June 1940, working up to his last days (Wegener and Köppen, 1955) on scientific publications, almost precisely 1 year before the completely unjustified attack of the "Deutsches Reich" on the Sovjet Union (Figs 5-7).

The Köppen family can be considered as an excellent example for the flow of scientists between western Europe and the Russian empire who made important contributions to the evolution of academic environments in Russia (Lüdecke, 2003), but in the case of Wladimir Köppen also moving from Russia to Germany, to a western country.

\section{Köppen and his impact on meteorology}

Wladimir Köppen spent a lot of time on the Crimea during his young years, visiting a high school in Simferopol. He caught a substantial interest in the vegetational zonations related to the morphology (and henceforth climate, temperature, precipitation) of the mountaineous southern Crimea. He actually wrote his very first publication about temperature variations in Karabakh (Wegener and Köppen, 1955).

Wladimir Köppen began his time as a student, first devoted to botany in St. Petersburg in Sept. 1864. His impressions from the Crimea motivated him to take up studies in meteorology and related subjects and he moved to the universities of Heidelberg and Leipzig in Germany where he acquired his doctorate in 1870 . He then moved back to Russia and he got his first position at the Central Physical Observatory in St. Petersburg (1872-1874) and deepened his knowledge of meteorological processes, in particular the global distribution of climatic zones.

This laboratory was under the leadership of Heinrich von Wild, a Swiss meteorologist who had moved to Russia, who had become a member of the Russian Academy of Sciences and president of the International Polar Commission. He was instrumental to organize 
the Russian contribution to the $1^{\text {st }}$ International Polar Year (IPY, 1882-1883), with an important scientific station on the island Sagastyr in the Lena Delta. This was some years after Köppen had moved to Hamburg and there can be no doubt that he played a pivotal role in the contacts between Georg Neumayer (Director of the "Deutsche Seewarte" in Hamburg) and Heinrich von Wild, his former boss when promoting the $1^{\text {st }}$ IPY.

He visited international meetings of meteorologists and soon became quite famous in Russia and abroad. He was then "discovered" by Georg Neumayer, founder and director of the "Deutsche Seewarte" in Hamburg (later the DHI = "Deutsches Hydrographisches Institut", nowadays the BSH = "Bundesamt für Seeschiffahrt und Hydrographie"), who on March 15, 1875 offered Köppen a position as department head in applied meteorology in his new institution. Neumayer was building up the "Deutsche Seewarte" and urgently needed qualified scientists. Köppen's department was commissioned to gather daily weather observations needed for sailing instructions. He published articles/books on the global climate zones (Köppen, 1923; Köppen, 1936) and already in young years he became a famous and well established leading meteorologist (cf. Wegener and Köppen, 1955, for a complete listing of his publications in German).

Georg Neumayer (since 1900 Georg Ritter von Neumayer, Fig. 5) was a towering figure in climate and in particular polar related sciences in Europe. He was the promoter of the 1. International Polar Year 1882/83 which was based on the original ideas of Carl Weyprecht (1838-1881) who, however, had died a few years before. Even though Wladimir Köppen was very young at that time, he excelled scientifically and it must have been very flattering for him to be invited as a scientist to serve at a renowned foreign hydrographic institution (from 1876 to 1919). His German roots may have helped, but it was probably the congenial scientific perspectives of Neumayer and Köppen, who brought these 2 scientists to work together for many years, until Georg von Neumayer retired in 1903, to return to the Palatinate where he originally came from. It soon became clear to both of them that weather services required international collaboration. Köppen became for some time department head for Weather Services/Applied Meteorology at this new institution, but was later relieved from the many administrative duties in favor of his scientific work and stayed there until retirement in 1919 (being succeeded by his son-in-law and close friend as well as scientific collaborator Alfred Wegener).

Köppen also played an important role within the German Meteorologic Society and the foundation of the German Weather Service replacing Neumayer after retirement (Tetzlaff, et al., 2008). In Germany, Köppen soon was involved in numerous professional activities as part of his duties at the "Deutsche Seewarte" (1875-1945) of the German (then mainly Prussian) Navy, which had evolved from the "Norddeutsche Seewarte", a private institution which had been led by Wilhelm von Freeden and which existed 1867-1875. Details of his scientific life in Hamburg can be found in (Wegener and Köppen, 1955), his biography compiled by his daughter based on his personal notes. A laudatio with many personal aspects has been published by his colleagues at the "Deutsche Seewarte" at the occasion of his $80^{\text {th }}$ birthday in 1926 (Deutsche Seewarte Hamburg, 1926). One particular interesting technical detail is the development of kite-technology for meteorologic measurements at height which led to the establishment of the kite-station of the "Deutsche Seewarte" in Gross Borstel in the northern suburbs of Hamburg. Already in young years he became a famous and well established leading meteorologist. 


\section{Köppen's cooperation with Alfred L. Wegener}

Alfred Wegener has worked and published about a very diverse and broad range of scientific subjects, on many of them by writing quite comprehensive books. His doctoral thesis (Wegener, 1905) dealt with the Alfonsinian Tables which comprise a medieval astronomical document allowing to calculate the positions of sun, moon and the five planets, certainly a strange subject. But it probably prepared Wegener later to occupy himself with the question of the Milankovitch frequencies. He later took up a truly meteorologic theme (Wegener, 1911) which made him to establish scientific contact with Wladimir Köppen who by that time was an established and experienced meteorologist and who commented extensively on Wegener's book about "Thermodynamik der Atmosphäre" (Deutsche Seewarte Hamburg, 1926).

During the early years of the last century the young Alfred Wegener contacted Wladimir Köppen on meteorologic questions, but also because he had the idea that the geography of planet Earth had gone through major changes. He wanted to prove through the means of reconstructions ("historic" - in a geological sense) of former climate zonations,

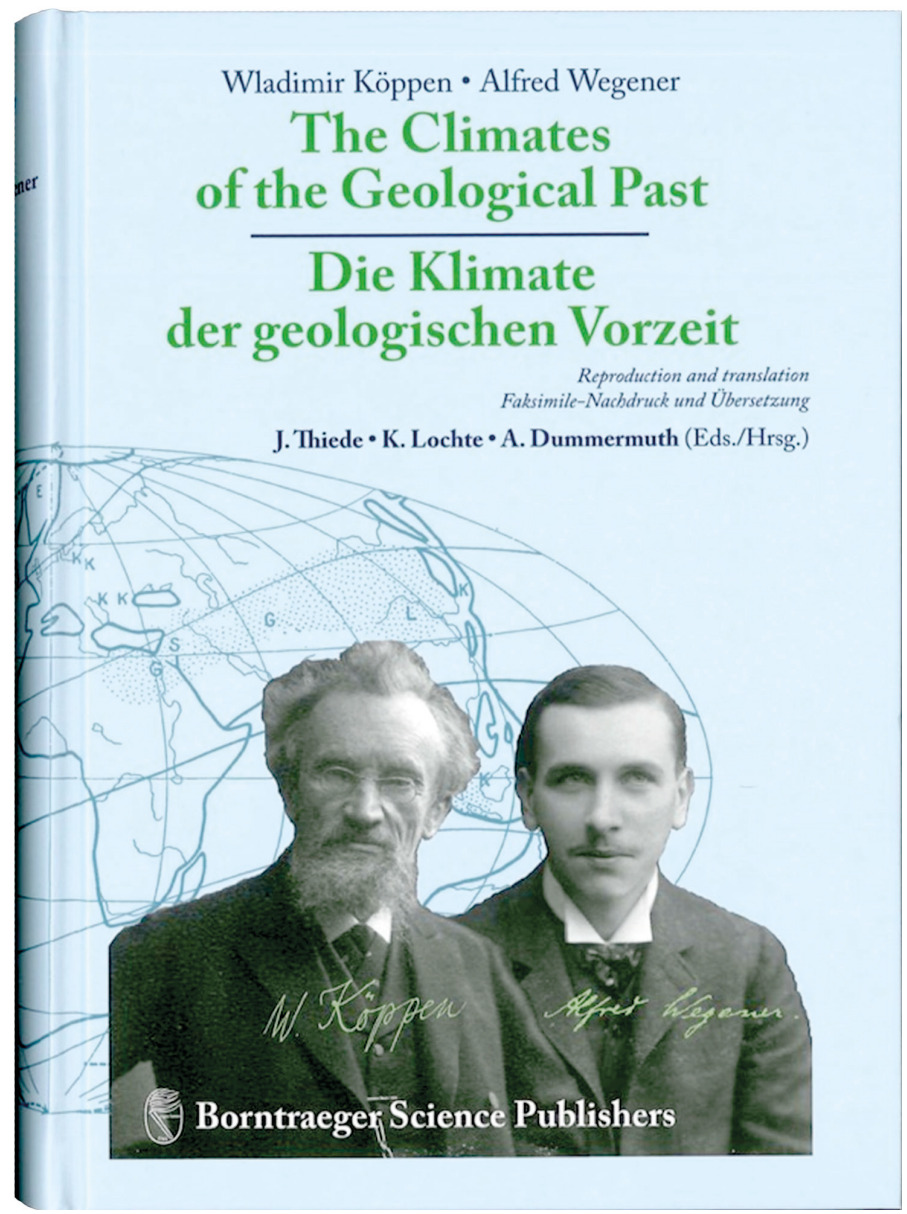

Fig. 8. Cover of the famous book of Köppen \& Wegener 1924, as reprinted in 2015, together with a translation into English 
which he believed to be stable as related to the geometry of the earth's orbit around the sun, but contrary to the changing geographic positions of the continents.

Alfred Wegener achieved world renown with the publication of his book "The Origin of Continents and Oceans" in 1915. With four editions printed between 1915 and 1929 (see Wegener, 2005), Wegener's hypothesis on the "origin of continents and oceans" was highly controversial at that time. At first, Köppen was skeptical of Alfred Wegner's ideas about the "Origin of Oceans and Continents" (Continental Drift Hypothesis), but later (around 1919; Deutsche Seewarte Hamburg, 1926) he changed his scientific position and became an ardent defender of Wegener's ideas. The peak of their scientific relationship was reached when Wladimir Köppen and Alfred Wegener jointly published their monograph on "Die Klimate der geologischen Vorzeit" (Climates of the Geological Past) in 1924, which has recently been republished (Fig. 8). This book contains an important monographic interpretation on the causal relationships of climate change in the geological past (Köppen and Wegener, 1924). Before his death in 1940 at the age of 93, Köppen made additions to their work under the title "Supplements and Corrections", notifying the printing office that he "urgently needed the proofs because he was dying" (Wegener and Köppen, 1955).

Only one edition of Köppen's \& Wegener's book of 1924 was printed and unfortunately, most copies of this edition were lost, including all originals, during World War II. Because of its importance in the light of modern climate and paleoclimate research, the Alfred-Wegener-Institute, Helmholtz Center for Polar and Marine Sciences in Bremerhaven/Germany together with the original publisher (Gebr. Borntraeger in Berlin) and with the support of a number of learned societies and research institutions in Germany decided to reprint this book (in its original form), and to furnish it with an English translation, in order to make it available to the wide modern international community of climate researchers.

Köppen's \& Wegener's book (1924) is of principal scientific interest for several reasons:

- it contains a systematic inventory and description of the sedimentological and paleontological arguments which Wegener used to establish his historic (in a geological sense) climate zones for most of the Paleozoic, Mesozoic and Cenozoic paleogeographic reconstructions. During the first two decades of the last century Köppen had developed important concepts of the modern global distributions of climate zones (see Köppen, 1923, 1936 for summaries). The close cooperation between Wegner and Köppen led to their mutual conviction that these zones could in principle also be deduced from the stratigraphic records of fossil climate indicators;

- the book critically describes and discusses paleogeographic reconstructions for most of the Phanerozoic periods. Because Köppen was fluent in Russian he was able to draw on information from many less known regions, for example, northern Eurasia;

- the book then ventures into hypothesizing about climate changes in Earth history. The most important element of this discussion stems from a close collaboration they had established with Milankovitch. He claimed and precisely calculated that the Late Cenozoic climate changes were controlled by systematic variations of some of the parameters controlling the geometry of the earth's orbit around the sun (eccentricity, obliquity, precession) generating differences in the insolation. Milankovitch actually allowed them to use his text, calculations and figures (Fig. 9); 

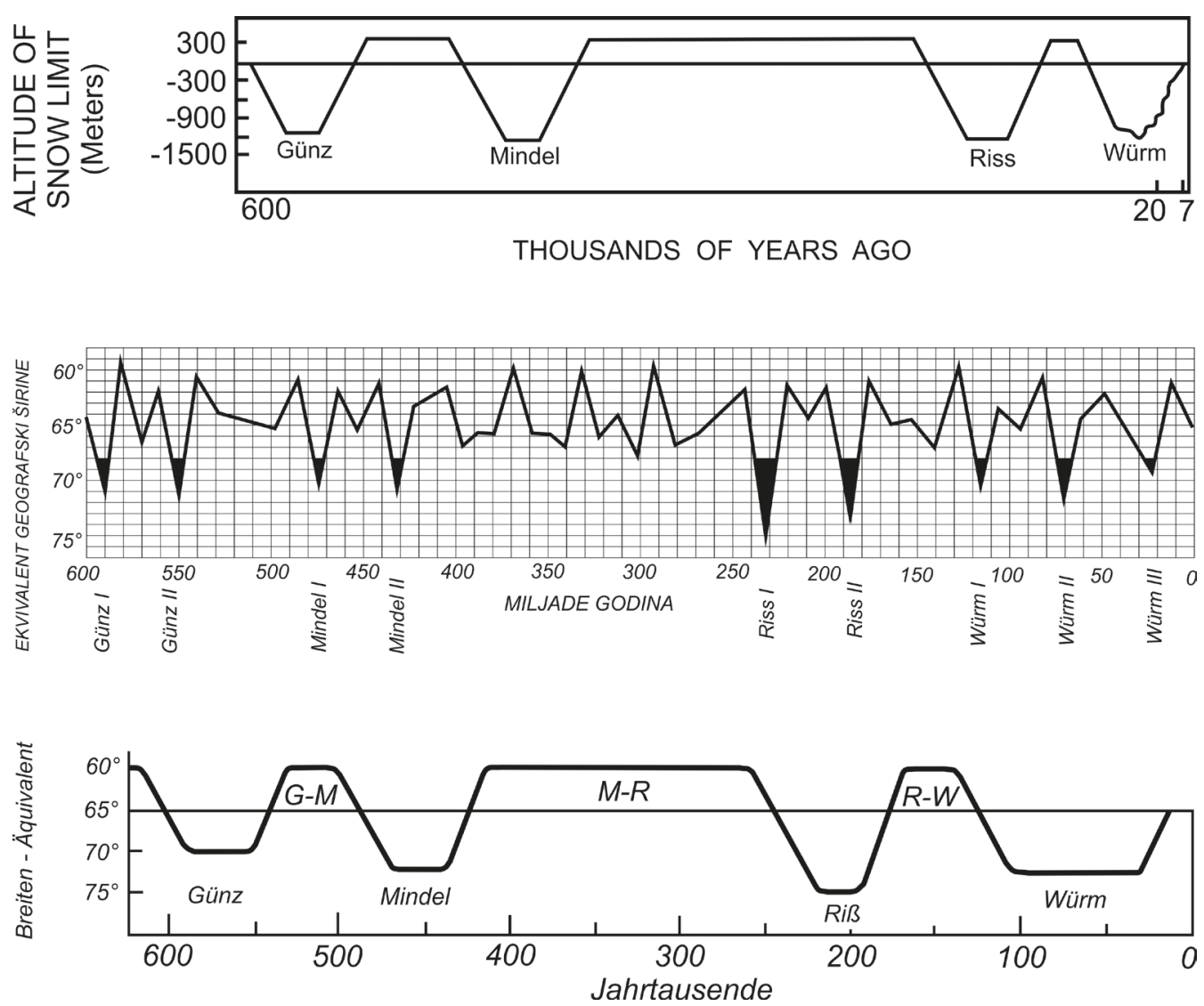

Fig. 9. Inclusion of Milankovitch data into Köppen's and Wegener's considerations. Uppermost panel: Penck and Brückner's curve showing the climate during the Pleistocene period (published 1909). Middle panel: Milankovitch's radiation curve for latitude $65^{\circ} \mathrm{N}$ forwarded to Köppen in 1924. Lower panel: Sequence of Late Qauternary Glacials and Interglacials (after Penck \& Brückner, 1909) adapted to their timing deduced from Milankovitch's radiation curve by drawing a horizontal line at latitude $65^{\circ} \mathrm{N}$ (cited from Berger, 1995)

- acceptance of the principles of the Milankovitch frequencies made it possible for the first time early in the last century to establish a precisely defined time scale of Late Cenozoic glacial-interglacial history. Later it was shown that Milankovitch frequencies could not only be reconstructed from Quaternary sediments, but that they could also be found in the cyclostratigraphy of deposits from many periods of the Phanerozoic (Schwarzacher, 1993, see below).

\section{Köppen's and Wegener's cooperation with Milankovitch}

When writing their book (Köppen and Wegener, 1924) the authors contacted Milutin Milankovitch who was engaged in calculating the geometric properties of the earth's orbit around the sun (eccentricity, obliquity, precession) and deducing from them regular insolation changes (mainly around a latitude of $65^{\circ} \mathrm{N}$ ). He believed that they controlled the Late Tertiary and Quaternary alternations between Glacials and Interglacials; he actually pro- 
vided figures to Köppen and Wegener (Fig. 9). His idea was by no means completely new, but originated from some British geoscientists in the early and middle $19^{\text {th }}$ century (a good historic account of the developments of this thinking can be found in Summerhayes 2015).

The scientific relationship between Milankovitch, Köppen and Wegener has been elucidated in a book edited by A. Berger (1995), based on the autobiography of Milankovitch, but widened in scope by remarks of the son Vlasko Milankovitch. The book contains facsimiles of the exchange of fascinating letters between Milankovitch, Köppen and Wegener on a variety of themes. The most important one was naturally the timing of insolation changes and the impact or changes of the geometry of the orbit of planet Earth around the sun on climate changes between glacials and interglacials during the most recent geological past (Milankovitch, 1941). But Wegener and Köppen also influenced Milankovitch's thinking on the causes of changes of the planetary magnetic field and its consequences on the paleopositions of poles ("movement of the poles" according to Berger, 1995) in the geologic past (with the ensuing consequences for the "Origin of Continents and Oceans" and their paleogeography). Together with Wegener he speculated a lot about the physical state of the interior of the Earth's interior and the causes of the changing magnetic field.

Milankovitch lived 1879-1958, hence he was junior to Köppen who was born in 1846, but born only shortly before Wegener's birth in 1880 . He died 13 years after the end of the $2^{\text {nd }}$ World War. He endured as a Serbian citizen the hardships of the $1^{\text {st }}$ World War which - however - provided him with the privilege to work after a short time as Austrian prisoner of war on his hypothesis of the relationship of the changes of the geometry of the earth's orbit around the sun. They had both encouraged Milankovitch, a Serbian engineer, to pursue this idea. He had studied in Vienna, had won many good friends in Austria who finally succeeded to get him out of the POW camp. He was then confined to the building of the Hungarian Academy of Sciences in Budapest, where he could work scientifically. He published his calculations extensively many years later (Milankovitch, 1941).

Köppen had contacted Milankovitch through letters since 1922 from Hamburg (Berger, 1995) but then Wegener, Köppen and Milankovitch met in person 1924 at a conference in Innsbruck (88 ${ }^{\text {th }}$ Conference of the "Gesellschaft deutscher Naturforscher und Ärzte" and paid each other personal visits after the Wegener- and Köppen-families had moved from Hamburg to Graz. The new book of Köppen \& Wegener (1924) about "Climates of the Geological Past" was about to be published and Wegener gave an extensive talk about his hypothesis of the "Origin of continents and oceans" as well as about his ideas on reasons for the climatic changes between Glacials and Interglacials. Milankovitch was deeply impressed that Wegener attended so much to his ideas. About a decade later, at an INQUA congress in Vienna Milankovitch was cornered by Albrecht Penck who together with Brückner had defined the late Quaternary subdivision of the Alpine Glacials and Interglacials, mainly based on morphologic and geological arguments (Penck and Brückner, 1909) and who was not willing to accept Milankovitch's arguments.

\section{The revival of the Milankovitch hypothesis during the later part of the $20^{\text {th }}$ century}

The Milankovitch-hypothesis to explain Quaternary Glacial and Interglacial climate variability was not very much in the public limelight for a long time, mainly because the accessible paleoclimatic archives (deep-sea sediments, ice cores, lake sediments, loess de- 
posits) could not be dated with sufficient precision. It was the revolutionary paper of Hays et al. (1976) on data from two southern Indian Ocean sediment cores, which were dated precisely and allowed the authors to prove the presence of the three dominant Milankovitch frequencies in the time series of the proxy data, which triggered the revival of the Milankovitch hypothesis.

Actually, its validity was hotly debated at first (and in some circles still is, see Karner and Muller, 2000) because it is believed that 1) the influence of the Milankovitch frequencies on the insolation changes is considered to be too weak to cause large climatic changes, 2) there is no real explanation of the $100 \mathrm{kyr}$-cycle (eccentricity, cf. Berger, 2012) and 3) thresholds and the cascades of processes in the climate system are too poorly known (Schellenhuber, 2009). However, this changed dramatically with the advent of modern dating techniques which allowed to "translate" the available stratigraphies into time series of climate relevant proxy data. Approx. 40 years ago Hays, et al. (1976) published their evidence for the presence of Milankovitch cyclicity in deep-sea sediments (see also Maslin, 2016) and revived a hypothesis which can be traced back to the early decades of the last century (Köppen and Wegener, 1924). Berger (1988) then published an excellent review of the relationship of the Milankovitch theory and climate and put its history into a historical context (Berger, 2012). The regular pace of the alternations of Glacials and Interglacials tempted people to model ice ages, climate cycles and the transitions between these two end members of the late Quaternary climates (Paul and Berger, 1997) who related them to the global carbon cycle and Shackleton 2000 seems agree to this conclusion.

\section{Evidence from deep-sea sediments and ice cores}

Nowadays the orbital parameters originally calculated by Milankovitch can be substantiated by means of time series obtained from deep-sea sediments (Hays, et al., 1976) and ice cores (Augustin et al., 2004) for the past. Milankovitch frequencies can also be quantitatively calculated/predicted for the future and are hence a powerful argument when debating future climatic scenarios (Thiede and Tiedemann, 1998). Consequently, this reflects an important piece of tradition in the development of our understanding of how climate evolved in the course of time, reaching from Köppen, Wegener and Milankovitch to modern days. The latter aspect is probably the most important scientific contribution of the book of Köppen and Wegener (1924) (however, see further below).

Imbrie, et al. (1993) widened the scope of the Milankovitch theory and considered the structure and origin of major glaciation cycles. They discussed in particular the impact of the 100000 year cycle which was considered to be far too weak to generate the large climate fluctuations, but found that "local responses over the 100000 year cycle are similar to those of the shorter Milankovitch frequencies implying that similar internal climatic mechanisms operate in all three of them". In detail, they documented that the last deglaciation was a clear response to orbital forcing. Rutherford and D'Hondt (2000) observed the important change of the pace of ice ages between 1.5 and 0.6 ma concluded that increased heat flow across the equator "triggered the transition to sustained 100-kyr glacial cycles".

Imbrie, et al. (1993) then extended their considerations over a two-million-year long time interval and detected that the dominance of the 100,000 year cycle was restricted to the younger part of the Quaternary. Further back in time it diminished and the 
dominance of the obliquity and precession related cycles became more important in controlling insolation, for reasons not clearly understood. They also define a substantial list of unresolved questions, namely of the physical mechanisms driving the orbitally forced responses to Milankovitch-driven changes in insolation or the feedbacks which drive the 100000 year cycle. Also the question how the Milankovitch driven cycles were interacting with cyclic processes which operate at higher frequencies, was left unresolved.

\section{Cyclostratigraphy and the Milankovitch theory as documented in sediments of pre-Quaternary periods of the Phanerozoic}

The discussions of the Milankovitch theory by Berger, et al. $(1988,2012)$ and Hays, et al. (1976) motivated colleagues studying cyclic sedimentation patterns originating from periods of the Phanerozoic other than the Quaternary in the context of their Milankovitch frequency control. It actually led to a revival of the hypothesis of the Milankovitch control of sedimentation patterns, because many formations consisted of sedimentary sequences with apparently cyclic repetitions of their individual layers, making it tempting to look for the cause of their cyclicity. This is not the place to cover this aspect completely, but it seemed important to point to the fact that Milankovitch frequencies and their impact on climatically sensitive depositional regimes can be observed during many times, both in marine as well as in terrestrial environments. Schwarzacher (1993) also considered a number of different "geological oscillators" which could generate cyclic sedimentation patterns, namely one related to the planet system, the other one related to self-oscillating systems, possibly related to the climate system.

As described in Schwarzacher (1993), cyclic sedimentations patterns or "cyclostratigraphies" have been observed in Precambrian to modern depositional environments. To link them to or maybe explain them by environmental changes caused by Milankovitch frequencies encounters several problems, namely sufficiently precise dating of sections as well as plausible causal explanations. The stratigraphic data need to be dated precisely before they can undergo transformation into time series and be subject to spectral analysis. In addition, Berger (1989) found out that precession has grown in duration from 16-19 kyrs during the Silurian to 19-23 kyrs during the Quaternary, obliquity 27-30 kyrs during Silurian to 42-54 kyrs during the Quaternary; he explained this to be due to the decreasing day length and the continuously increasing earth moon distance.

Examples of cyclic sedimentation pattern which could have been caused by environmental change in response to Milankovitch frequencies have been found in marine, lacustrine, evaporitic and fluvial environments. Famous are the Jurassic marl-limestone cycles (Seibold, 1951) in Germany, the shale-limestone cycles of the Mesozoic (Schwarzacher and Fischer, 1982) or the cyclic sediments of the lacustrine Green River Formation (Eocene) in the US (Fischer and Roberts, 1991). However, how the cyclic sedimentation patterns caused by transgressions and regressions along continental margins (Vail, et al., 1991) can be linked to Milankovitch frequencies, remains another open problem. 

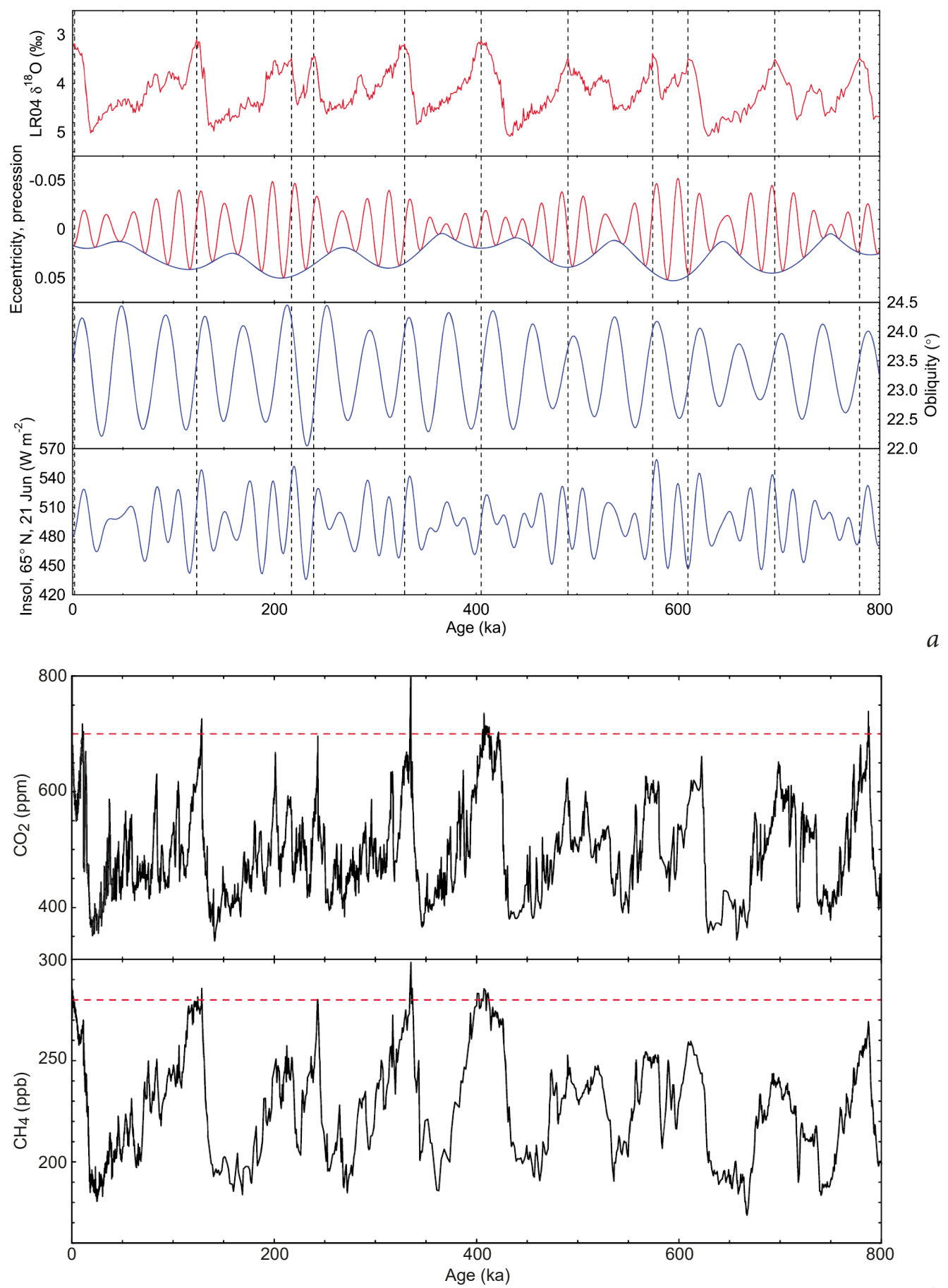

Fig. 10. Complex data set of Past Interglacials Working Group of PAGES, 2016: a) identification of interglacial peaks and insolation parameters, and $b$ ) concentrations of atmospheric greenhouse gases over the last 800,000 years, based on measurements in Antarctic ice cores 


\section{Modern Insights into the Milankovitch-frequencies and their impact on climate change}

The foundations of paleoclimate research laid by Wladimir Köppen and Alfred Wegener are expanded today in many laboratories worldwide. The Alfred Wegener Institute Helmholtz Center for Polar and Marine Research in Bremerhaven, Germany, researches past, present and future climate changes from a polar perspective. Based on traces enshrined in ice cores and sediment cores, reconstruction of past climates is now possible in much greater detail due to the development of new proxies. It enables not only analysis of paleotemperatures, but also of ice coverage, carbon dioxide and methane in the atmosphere, wind speed and many other variables of past climates.

The understanding of paleoclimate processes and global linkages are fundamental to assess potential future developments. In contrast to Köppen's and Wegener's times, however, nowadays not only the natural dynamics are shaping the climate, but also anthropogenic impacts have to be considered complicating the already complex matter of climate processes.

André Berger $(1988,2012)$ has revisited this entire complex in modern times. The Milankovitch frequencies of the orbital parameters control insolation; they can be calculated precisely for the past and for the future. Recently the Past Interglacials Working Group of PAGES (2016) led by A. Berger have compiled a complex data set about the duration and properties of the Interglacials over the last 800,000 years (Fig. 10) and they came to the following conclusions: 1 ) Transitions from Glacials to Interglacials (socalled Terminations) "involve rapid, non-linear reactions of ice volume, $\mathrm{CO}_{2}$ and temperature to external astronomical forcing", and 2) "The combination of minimal reduction in northern summer insolation over the next few orbital cycles, owing to low eccentricity, and high atmospheric greenhouse gas concentrations implies that the next glacial inception is many tens of millennia in the future".

\section{Conclusions}

- Orbital parameters have long been suspected to have a major impact on climate variability. But it was M. Milankovitch who systematically investigated their properties and introduced their obvious impact into the past climate variability.

- The congenial cooperation of Köppen, Wegener and Milankovitch resulted in a revolution of our understanding of timing and mechanisms of the late Quaternary climate variabilty.

- The advent of modern dating techniques of climate archives in ice cores, deepsea, lake and loess sediments finally resulted in the definition of the Milankovitch frequencies in historic records (in a geological sense).

- The scientific legacies of Wladimir Köppen and Alfred Wegener are also pursued at the Alfred-Wegener-Institute, Helmholtz Center for Marine and Polar Research in Bremerhaven (Germany), Wegener Center for Climate and Global Change, an interdisciplinary and internationally oriented institute of the Karl Franzens University Graz (Austria) and the recently founded Köppen-Laboratory of Geochronology at the State University of Saint Petersburg (Russian Federation). 


\section{Acknowledgements}

I am grateful for the help of many who contributed to this article by helping me to visit the places where the Köppen-family lived. I got additional information from Dr. Günther Schönharting (Schloss Eichhofen in Bavaria/Germany, the grandgrandson of Wladimir Köppen and hence the grandson of Alfred Wegener), as well as from Dr. Chekin (Moscow and Springfield/VA-USA, a distant relative of the Köppen-family) and Dr. Snigirevsky (director of the SPbGU field station on Crimea). The caretakers of the archives of the AWI, of the BSH and of the DWD as well as the director of the library of Saint Petersburg State University Marina Karpova, were extraordinarily helpful by providing information, in particular pictures. Two unkown Russian referees pointed out minor mistakes in the manuscript.

\section{References}

Agassiz, L., 1838. On the erratic blocks of the Jura. Edinburgh New Philos. J. 24, 176-179.

Augustin, L., Barbante, C., Barnes, P. R., Barnola, J. M., Bigler, M., Castellano, E., Cattani, O., Chappellaz, J., Dahl-Jensen, D., Delmonte, B., Dreyfus, G., Durand, G., Falourd, S., Fischer, H., Flückiger, J., Hansson, M.E., Huybrechts, P., Jugie, G., Johnsen, S. J., Jouzel, J., Kaufmann, P., Kipfstuhl, J., Lambert, F., Lipenkov, V.Y., Littot, G. C., Longinelli, A., Lorrain, R., Maggi, V., Masson-Delmotte, V., Miller, H., Mulvaney, R., Oerlemans, J., Oerter, H., Orombelli, G., Parrenin, F., Peel, D. A., Petit, J. R., Raynaud, D., Ritz, C., Ruth, U., Schwander, J., Siegenthaler, U., Souchez, R., Stauffer, B., Steffensen, J. P., Stenni, B., Stocker, T. F., Tabacco, I. E., Udisti, R., Van De Wal, R. S., Van Den Broeke, M., Weiss, J., Wilhelms, F., Winther, J.G., Wolff, E. W., Zucchelli, M., 2004. Eight glacial cycles from an Antarctic ice core. Nature 429, 623-628.

André, P., Berger, W.H., 1997. Modellierung der Eiszeiten: Klimazyklen und Klimaübergänge. Geowissenschaften 15 (1), 20-27.

Berger, A., 1984. Accuracy and frequency stability of the Earth's orbital elements during the Quaternary, in: Berger, A., Imbrie, J., Hays, J., Kukla, G., Saltzman, B. (Eds.). Milankovitch and Climate. D. Reidel, Dordrecht, 3-40.

Berger, A., 1988. Milankovitch Theory and Climate. Rev. Geophys. 26 (4), 624-657.

Berger, A., 1989. Pre-Quaternary Milankovitch frequencies. Nature, 342, 133.

Berger, A. (ed.), 1995. Milutin Milankovic 1879-1958 (from his autobiography with comments by his son, Vasko and a preface by André Berger). Europ. Geophys. Soc., FRG, Katlenburg-Lindau.

Berger, A., 2012. A Brief History of the Astronomical Theories of Paleoclimates, in: Climate Change: Inferences from Paleoclimate and Regional Aspects / Berger, A., Mesinger, F., Sijacki, D. (Eds.). Springer, Verlag, Wien, 107-129.

Berger, W.H., 2012. Milankovitch Theory - Hits and Misses. Scripps Inst. Techn. Rep. (01-16-2012), La Jolla CA.

Budyko, M.I., Ronov, A. B., Yanshin, A. L., 1987. History of the Earth's Atmosphere. Springer, Berlin-Heidelberg.

Deutsche Seewarte Hamburg (ed.), 1926. Köppen-Heft, Ann. Hydrogr. Marit. Meteor. 1926, 1-11.

Esmark, J., 1824. Bidrag til vor jordklodes historie. Magazin Naturvidenskab, 2(1), 29-54.

Fischer, A. G., Roberts, L. T., 1991. Cyclicity in the Green River Formation (Lacustrine Eocene) of Wyoming. J. Sediment. Petrol. 61(7), 1146-1154.

Hays, J. D., Imbrie, J., Shackleton, 1976. Variations in the Earth's orbit: Pacemaker of the ice ages. Science 194, 1121-1132.

Imbrie, J., Berger, A., Shackleton, N. J., 1993. Role of Orbital Forcing: A Two-Million-Year Perspective, in: Global changes in the Perspective of the Past / Eddy, J. A., Oeschger, H. (Eds.). John Wiley \& Sons, Inc., Hoboken, NJ., 263-277.

Imbrie, J., Berger, A., Boyle, E. A., Clemens, S. C., Duffy, A., Howard, W. R., Kukla, G., Kutzbach, J., Martinson, D. G., Mcintyre, A., Mix, A. C., Molfino, B., Morley, J. J., Peterson, L. C., Pisias, N. G., Prell, W. L., Raymo, M.E., Shackleton, N. J., Toggweiler, J. R., 1993. On the structure and origin of major glaciation cycles. Paleoceanography, 8 (6), 699-735. 
Karner, D. B. \& Muller, R. A., 2000. A Causality Problem for Milankovitch. Science 288, 2143-2144.

Khayrullin, K. Sh., 2016. Vladimir P. Keppen (1846-1940) [Keppen Vladimir Petrovich. K 170-letiyu so dnya rozhdeniya (1846-1940)]. Proc. Voeikov Main Geophys. Lab., 583, 264-270 (in Russian).

Köppen, W. P., 1923. Die Klimate der Erde. Walter de Gruyter, Berlin.

Köppen, W., 1936. Das geographische System der Klimate. Handbuch der Klimatologie. Vol. 1C / Köppen, W., Geiger, R. (Eds.), Borntraeger, Berlin.

Köppen, W., Wegener, A., 1940. The Climates of the Geological Past — Supplements and Corrections, Publ. Gebr. Borntraeger, Berlin.

Köppen, W., Wegener, A., 2015. The Climates of the Geological Past (Die Klimate der geologischen Vorzeit) / Thiede, J., Lochte, K., Dummermuth A. (Eds.). Reprint of the original German edition and complete English translation. Borntraeger Scientific Publishers, Stuttgart.

Ma, C., Meyers, S. R., Sageman, B. B., 2017. Theory of chaotic orbital variations confirmed by Cretaceous geological evidence. Nature 542, 468-470.

Maslin, M., 2016. Forty years of linking orbits to ice ages. Nature 540, 208-210.

Milankovic, M., 1941. Kanon der Erdbestrahlung und seine Anwendung auf das Eiszeitenproblem. Belgrade, Royal Serbian Acad. Sciences, Spec. Publ. 132, Sect. Math. Nat. Sci., 33, 633.

Berger, A., Crucifix, M., Hodell, D. A., Mangili, C., McManus, J.F., Otto-Bliesner, B., Pol, K., Raynaud, D., Skinner, L.C., Tzedakis, P.C., Wolff, E.W., Yin, Q.Z., Abe-Ouchi, A., Barbante, C., Brovkin, V., Cacho, I., Capron, E., Ferretti, P., Ganopolski, A., Grimalt, J.O., Hönisch, B., Kawamura, K., Landais, A., Margari, V., Martrat, B., Masson-Delmotte V., Mokeddem, Z., Parrenin, F., Prokopenko, A. A., Rashid, H., Schulz, M., Vazquez Riveiros, N., 2016. Interglacials of the last 800,000 years. Rev. Geophys. (AGU), doi: 10 1002/2015RG000482.

Paul, A., Berger, W.H., 1997. Modellierung der Eiszeiten: Klimazyklen und Klimaübergänge. Geowissenschaften 15(1), 20-27.

Penck, A., Brückner, E., 1900. Die Alpen im Eiszeitalter. Tauchnitz, Leipzig.

Rutherford, S. \& D'Hondt, S., 2009. Early onset and tropical forcing of 100,000-year Pleistocene glacial cycles. Nature 408, 72-75.

Schellenhuber, H. J., 2009. Tipping elements in the Earth System. Proc. Nat. Acad. Sci. USA 106 (no. 49), 20561-20563.

Schulz, M., Berger, W.H., Sarnthein, M., Grootes, P. M., 1999. Amplitude variations of 1470-year climate oscillations during the last 100,000 years linked to fluctuations of continental ice mass. Geophys. Res. Lett. 26 (22), 3385-3388.

Schwarzacher, W., 1993. Cyclostratigraphy and the Milankovitch Theory. Dev. Sediment. 52, Elsevier, Amsterdam, 225.

Schwarzacher, W. \& Fischer, A. G., 1982. Limestone-shale bedding and perturbations in the Earth's orbit, in: Einsele, G. \& Seilacher, A. (eds.), Cyclic and Event Stratification, Springer, Berlin, 72-95.

Shackleton, N. J., 2000. The 100,000-Year Ice-Age Cycle identified and found to lag Temperature, Carbon Dioxide, and Orbital Eccentricity. Science 289, 1897-1902.

Shackleton, N. J., Imbrie, J., 1990. The $\mathrm{d}^{18} \mathrm{O}$ spectrum of oceanic deep water over a five decade band. Climatic Change 16, 217-230.

Seibold, E., 1951. Chemische Untersuchungen zur Bankung im unteren Malm Schwabens. N. Jb. Geol. Paläont. Abh. 95, 338-370.

Sierro, F. J., Ledesma, S., Flores, J.-A., Torrescusa, S., del Olmo, W.M., 2000. Sonic and gamma-ray astrochronology: Cycle to cycle calibration of Atlantic climatic records to Mediterranean sapropels and astronomical oscillations. Geology 28 (8), 695-698.

Summerhayes, C. B., 2015. Earth's Climate Evolution. J. Wiley and Sons, Ltd., Chichester.

Tetzlaff, G., Lüdecke, C., Behr, H.D. (eds.), 2008. 125 Jahre Deutsche Meteorologische Gesellschaft. Ann. Meteorolog. (DWD) Offenbach., 43, 160.

Thiede, J., Tiedemann, R., 1998. Die Alternative: Natürliche Klimaveränderungen - Umkippen zu einer neuen Kaltzeit, in: Lozán, J. L., Graßl, H. \& Hupfer, P. (eds), Warnsignal Klima - Das Klima des 21. Jahrhunderts. Wissenschaftliche Auswertungen/ GEO, Hamburg, 190-196.

Tredakis, P.C., Crucifix, M., Mitsui, T. \& Wolff, E. W., 2017. A simple rule to determine which insolation cycles lead to interglacials. Nature 542, 427-432.

Vail, P.R., Audemard, F., Bowman, S.A., Eisner, P.N., Perez-Crus, C., 1991. The stratigraphic signatures of tectonics, eustasy and sedimentology, an overview, in: Einsele, G., Ricken, W., Seilacher, A. (eds.). Cycles and Events in Stratigraphy. Springer, Berlin, 617-659. 
Wang, L., Sarnthein, M., Erlenkeuser, H., Grootes, P. M., Grimalt, J. O., Pelejero, C., Linck, G., 1999. Holocene Variations in Asian Monsoon Moisture: A Bidecadal Sediment Record from the South China Sea. Geophys. Res. Lett. 26 (18), 2889-2892.

Wegener, A., 1905. Die Alfonsinischen Tafeln für den Gebrauch eines modernen Rechners, Diss. FriedrichWilhelms-Univ. Berlin, E. Ebering, Berlin.

Wegener, A., 1911. Thermodynamik der Atmosphäre, Leipzig.

Wegener, A., 1912. Neue Ideen über die Herausbildung der Grossformen der Erdoberfläche (Kontinent und Ozeane) auf geophysikalischer Grundlage. Announcement of an oral presentation at the main Annual Meeting of the Geologische Vereinigung, Jan. 6, Frankfurt/Main.

Wegener, A., 2005. Die Entstehung der Kontinente und Ozeane. Reprint of the first (1915) and fourth edition (1929) with handwritten remarks of Alfred Wegener / Krause, R., Schönharting, G., Thiede, J. (Eds.). Gebr. Borntraeger, Stuttgart.

Wegener-Köppen, E., 1955. Wladimir Köppen - ein Gelehrtenleben. Publ. Wissenschaftliche Verlagsgesellschaft m. b. H., Stuttgart.

Received: 17.09.2017

Accepted: 9.04.2018

Author's information:

Jörn Thiede — jthiede@geomar.de

\section{Владимир Кёппен, Альфред Вегенер и Милутин Миланкович: их влияние на современные исследования палеоклимата и возрождение гипотезы Миланковича}

\section{Й. Тиде}

Санкт-Петербургский государственный университет, Российская Федерация, 199034, Санкт-Петербург, Университетская наб., 7-9

Для цитирования: Thiede J. Wladimir Köppen, Alfred Wegener, and Milutin Milankovitch: their impact on modern paleoclimate research and the revival of the Milankovitch hypothesis // Вестник Санкт-Петербургского университета. Науки о Земле. 2018. Т. 63. Вып. 2. С. 230-250. https://doi. org/10.21638/11701/spbu07.2018.207

Владимир Кёппен (1846-1940, родился в Санкт-Петербурге, Россия), Альфред Вегенер (1880-1930, родился в Берлине, Германия) и Милутин Миланкович (1879-1958, родился в Дале, Хорватия) в начале XX века внесли значительный вклад в палеоклиматологию. Кёппен описал глобальную климатическую зональность, Вегенер создал теорию дрейфа континентов в фанерозое, используя климатические зоны Кёппена для описания палеогеографических сценариев геологического прошлого, а Миланкович предложил использовать вариации параметров орбиты Земли в качестве причины климатических изменений, обеспечивая точность датирования ледниковых и межледниковых эпох в четвертичном периоде. Объединив научные усилия и используя свой научный опыт и широкие научные интересы, им удалось коренным образом изменить наше понимание истории Земли. Научная деятельность Владимира Кёппена началась с проведения метеонаблюдений в Крыму и с участия в создании синоптических карт погоды во время работы в Центральной физической обсерватории в Санкт-Петербурге. Позже он продолжил свою научную карьеру в морской обсерватории Deutsche Seewarte в Гамбурге. Параллельно с работой над многочисленными публикациями Кёппен занимался развитием технологий метеонаблюдений и формированием организационных основ для метеорологии на национальном, а также и на 
международном уровнях. Одно из его основных научных достижений - схема глобальной климатической зональности, которая была неоднократно опубликована при жизни ученого и используется до сих пор.

Ключевые слова: палеоклиматология, ледниковые и межледниковые эпохи, циклы Миланковича, циклостратиграфия, Владимир Кёппен, Альфред Вегенер, Милутин Миланкович.

Контактная информация:

Йорн Тиде - jthiede@geomar.de 